\title{
ANALYSIS OF RAINFALL INFLUENCE IN BIOGAS PRODUCTION AND VARIATIONS IN THE SELF-POTENTIAL IN A RIO CLARO SANITARY LANDFILL (BRAZIL).
}

\author{
ANÁLISE DA INFLUÊNCIA DA CHUVA NA PRODUÇÃO DE BIOGÁS E VARIAÇÕES NO \\ POTENCIAL ELÉTRICO NATURAL NO ATERRO SANITÁRIO EM RIO CLARO (BRASIL).
}

\author{
César Augusto MOREIRA ${ }^{1}$, Lívia Portes Innocenti HELENE ${ }^{2}$, Fernanda CAVALLARI ${ }^{2}$, \\ Leonardo Paioli CARRAZZA ${ }^{2}$, João Carlos DOURADO ${ }^{1}$ \\ (1) Universidade Estadual Paulista, UNESP. Instituto de Geociências e Ciências Exatas. Rio Claro, São Paulo, Brazil. \\ Emails: moreirac@rc.unesp.br; jdourado@rc.unesp.br \\ (2) Universidade Estadual Paulista, UNESP. Geoscience and Environment Graduate Program. Rio Claro, São Paulo, Brazil. Emails: \\ liviapihelene@gmail.com; fee.cavallari@gmail.com; leopcarrazza@hotmail.com
}

\author{
Abstract \\ Resumo \\ Introduction \\ Material and Methods \\ Discussion of Results \\ Conclusions \\ References
}

\begin{abstract}
Biogas is a chemical compound rich in methane, generated by the degradation of organic matter, flammable power and applicable to energy generation. Landfills are areas with great potential for biogas generation due to the large amount of organic matter contained in solid domestic waste, particularly in Brazil, where around 50\% of the volume of waste is composed of organic matter. The sizing and design of projects to capture and generate energy in landfills depend on reliable estimates of future generation of biogas. The currently available models are deficient due to the exclusion of relevant factors in the biogas generation process. This paper discusses variations in natural electrical potential measured in periods every two weeks during 1 year by geophysical logging, and its relations with rainfall and biogas production measured in drains localized in areas with different ages of residues in sanitary landfill. The area with the recent waste (up to 3 months) and with greater availability of organic matter degradable presented the larger flow rates of biogas and values of electric potential more negative (average of $-200 \mathrm{mV}$ ). An area with old waste (over 15 years), where the flow of biogas was lower and the values of electric potential were neutral (average of $0 \mathrm{mV}$ ). The results suggest the possibility of using measures of electric potential natural on mapping regions of greatest generation of biogas, with possibilities of optimization of systems for capturing and generation of electricity by burning methane in landfills.
\end{abstract}

Keywords: geophysics, self-potential, methane, organic matter, rainfall.

RESUMO - O biogás é um composto químico rico em metano gerado a partir da degradação da matéria orgânica, com alto poder inflamável e, portanto, aplicável a geração de energia. Aterros sanitários são áreas com grande potencial de geração de biogás devido as grandes quantidades de matéria orgânica na composição dos resíduos sólidos domiciliares, particularmente no Brasil, onde cerca de 50\% do volume de resíduos sólidos é constituído por matéria orgânica. O dimensionamento e a elaboração de projetos de captação e geração de energia em aterros sanitários dependem das estimativas de geração desse biogás. Os modelos disponíveis atualmente são deficientes principalmente por desconsiderar aspectos relevantes no processo de geração do biogás. Este trabalho discute variações no potencial elétrico natural medido em períodos quinzenais durante 1 ano por meio de perfilagem geofísica, e suas relações com chuvas e produção de biogás medida em drenos localizados em áreas de resíduos com idades distintas num aterro sanitário. A área com resíduos recente (até 3 meses) e com maior disponibilidade de matéria orgânica degradável, apresentou as maiores vazões de biogás e valores de potencial elétrico mais negativos (-200mV em média). A área com resíduos antigos (mais de 15 anos), onde a vazão de biogás foi menor e os valores de potencial elétrico foram neutros ( $0 \mathrm{mV}$ em média). Os resultados sugerem a possibilidade do uso de medidas de potencial elétrico natural no mapeamento de regiões de maior geração de biogás, com possibilidades de otimização de sistemas de captação e geração de eletricidade pela queima de metano em aterros sanitários.

Palavras-chave: geofísica, potencial espontâneo, metano, matéria orgânica, chuva.

\section{INTRODUCTION}

The use of renewable resources as a source of clean and sustainable energy increasingly gains importance in the national and international levels, facing a reality of increasing global warming and its consequences because of the intensification of anthropogenic carbon emissions in generating electricity, as happens with coal thermoelectric plants.

Biogas is a gas mixture resulting from the anaerobic degradation of organic material in solid waste deposited in sanitary landfills and from industrial effluents and domestic sewage treated by the anaerobic process (Christensen et al., 2001; Kumar, 2012). This compound has great potential for energy use in Brazil, in a scenario where sanitary landfills have significant relevance as depository of large amounts of organic matter (CETESB / SMA, 2006).

Among the main methodologies to estimate the volume of biogas production in projects of 
energy recovery, noteworthy is the proposal of the Intergovernmental Panel on Climate Change (IPCC, 1996), for state or national scenarios, or that proposed by the U.S. Environmental Protection Agency (USEPA, 1996), for processing or conditioning units of waste. Other theoretical methods are found in Laquidara et al. (1986), Tchobanoglous et al. (1993) and Oonk \& Boom (1995).

A comparative analysis of these methodologies is performed in Ensinas (2003), who considered them inadequate to the study of generation in landfill, by the use of default values or simply by disregarding important factors such as the potential for methane generation of waste and the production rate of biogas. The development or adaptation of technical analysis of dynamic and complex processes such as the generation of biogas in landfills are needed before the finding of deficiencies in current evaluation methodologies.

Geophysics is a science that studies geologic materials, structures and layers, be them constituents of the Earth or other planets, through the analysis of intrinsic physical parameters such as density, radioactivity, magnetization, and others, using tools that allow indirect measures with versatility in terms of research depth and coverage range (Milson \& Eriksen, 2011).

The logging at a site of geophysics applied in data acquisition and analysis of physical properties on exploratory wells or holes through instrument similar to that used in the surface acquisitions, though with reading sensors adapted for drilling (Elis \& Singer, 2008). It has applications in hydrogeological and environmental studies, but large-scale use in hydrocarbon research. Physical parameters measurements such as electrical resistivity and radioactivity are part of routine investigations on exploratory holes or for detailing in oil fields, due to the possibility of estimating lithological parameters such as permeability, porosity, grain size, types of rocks, among others (Asquith \& Gibson, 1982). Several studies suggest the possibility of using Electrical geophysical methods in studies of migration of contaminants originated from surface sources as an aid tool in understanding processes related to biodegradation of organic compounds or decomposition of organic matter in landfill (Meju, 2000; Georgaki et al., 2008; Moreira et al., 2013; Moreira et al., 2016).

The Self-potential is a geophysical method based on the phenomenon of generation of natural electrical potential from various physical and chemical processes. It is used for mineral exploration is widespread and mention back to work described in the late nineteenth century, mainly based on the difference in electrical potential or oxidation potential between bodies of metallic ores and rocks around (Milson \& Eriksen, 2011).

In the works of Naudet et al. (2003) measurements of self-potential concomitant to measures of potential oxidation/reduction (Eh), in the study of the evolution of a plume of contamination coming from a landfill in Entressen (France) are used. The results indicate that the electric potential decreases progressively in the aerobic zone, increases dramatically in the front of oxidation/reduction and finally reaches the standard of the area of the studies when it achieves the oxidation zone. In profile, there is a strong correlation between natural electric potential and potential measurements of oxidation/reduction.

In work developed on the ditch dump located in Cordeirópolis (Brazil) by Moreira et al. (2013), with readings of self-potential acquired in a regular mesh, on ditches of solid domestic waste with closing ages ranging from 2001 to 2007. The statistical analysis of the data indicates a direct correlation between waste age and positive values of electrical potential, where for recent trenching predominate values near zero in contrast to increasingly positive values for older trenches, attributed to decreased availability of organic matter susceptible to degradation.

Although there are, many studies that describe the use of geophysical methods in environmental diagnosis of landfills, most of these works essentially aim at the characterization of site with contamination plume. However, there are few studies aimed at determining relationships between self-potential and biological and physicochemical processes and their relationship to the production of leachate and landfill biogas (Naudet et al., 2003; Georgaki et al., 2008; Moreira et al., 2013, Moreira et al., 2016). This paper proposed the development of a static system of logging geophysical in the municipal 
sanitary landfill in Rio Claro city (Brazil), for measure of natural electrical potential (in Volts) in periods every two weeks during 1 year, and analysis of the relations with rainfall and biogas production measured in drains localized in areas with different ages of residues in sanitary landfill.

\section{MATERIALS AND METHODS}

The study site is located in the Rio Claro city, São Paulo State, Brazil, with the main access route by Highway Cornelio Pires (SP127), which makes the link between Rio Claro and Piracicaba cities. The landfill receives an average of 5000 tons of municipal solid waste per month, as an area of 142000 square meters and has been active since 2001 (Figure 1).

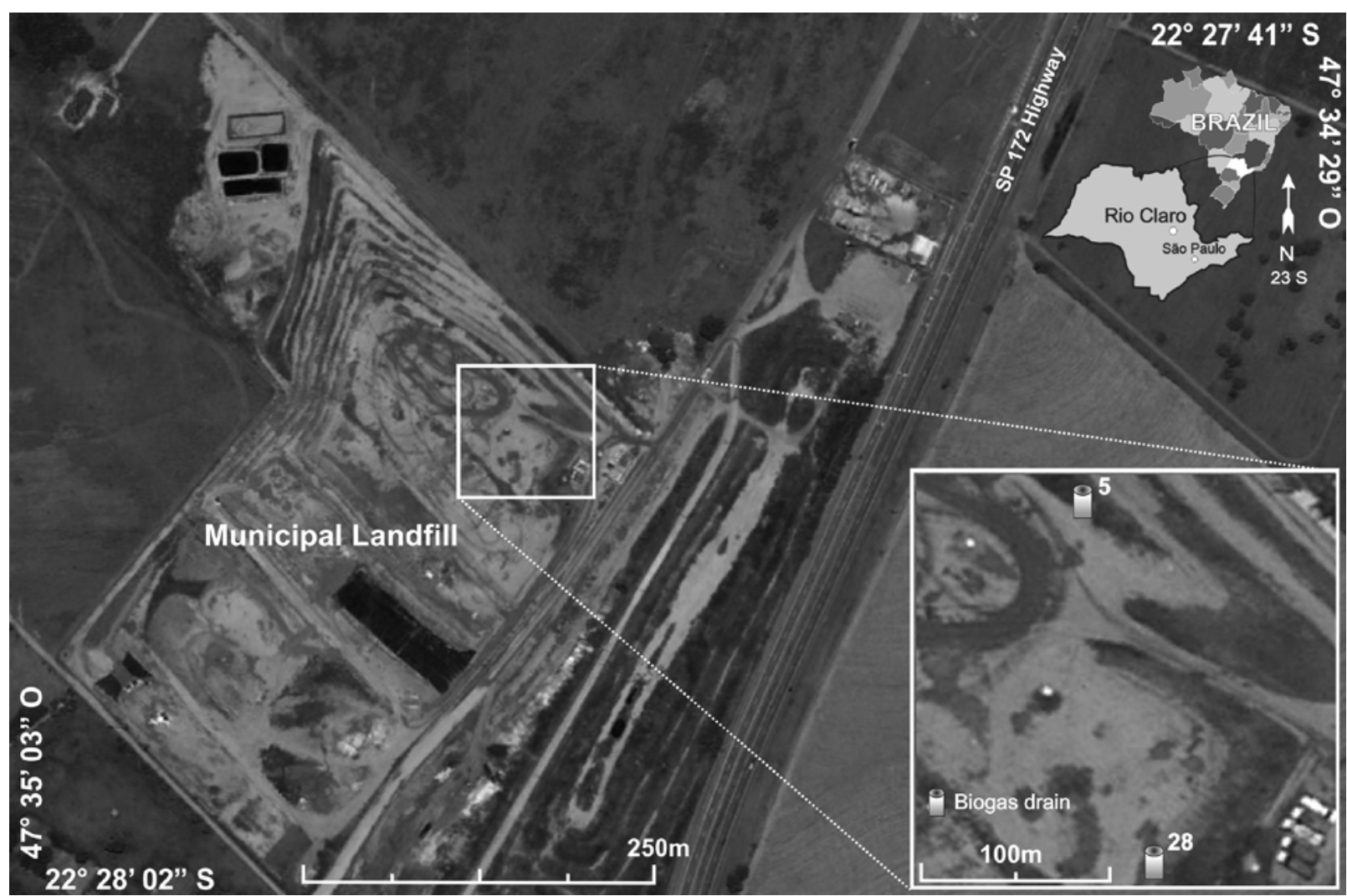

Figure 1 - Localization of study area, with details of biogas drain analyzed.

The construction scheme of the landfill comprises the local topography and consists of opening individual cells with $200 \mathrm{~m}$ long and $50 \mathrm{~m}$ wide, for the excavation of rock types from Rio Claro Formation and from the top of Corumbataí Formation from northeast to southeast direction, with gradients of about $1 \%$ to northeast. The landfill has basal and side impermeabilization sealing with a blanket of HDPE 2mm thick. A network to collect and drain the leachate leads the flow by gravity to the terminal boxes, and then to aeration lagoons for treatment.

The waste is dumped directly into cells by tipper trucks of urban collecting, later leveled to horizontal landings by action of bulldozers, daily covered by soil/sediment stored after excavation of the cell, with plastic, rubber, paper and other materials are distributed randomly, together with organic matter (Figure 2A). At this stage, vertical drains are installed for plumbing and atmospheric dissipation of biogas generated by the decomposition process of organic matter in waste, constantly alternated as new levels are built.

The final level is covered by a layer of about $1 \mathrm{~m}$ of soil/clay pellet, with a slope of $2 \%$ for surface water runoff (Figure 2B). Dikes marginal to the limits of the upper level are built, to direct the flow of rainwater by laminar flow and attenuation processes of lateral erosion (Figure 2C). Drains are ended by steel tubes coated by concrete pipes for burning biogas and dissipation of the generated heat (Figure 2D). Drains are constantly lit for consumption of the biogas by burning in an attempt to prevent accumulation in large scale and minimize the risk of explosion. 

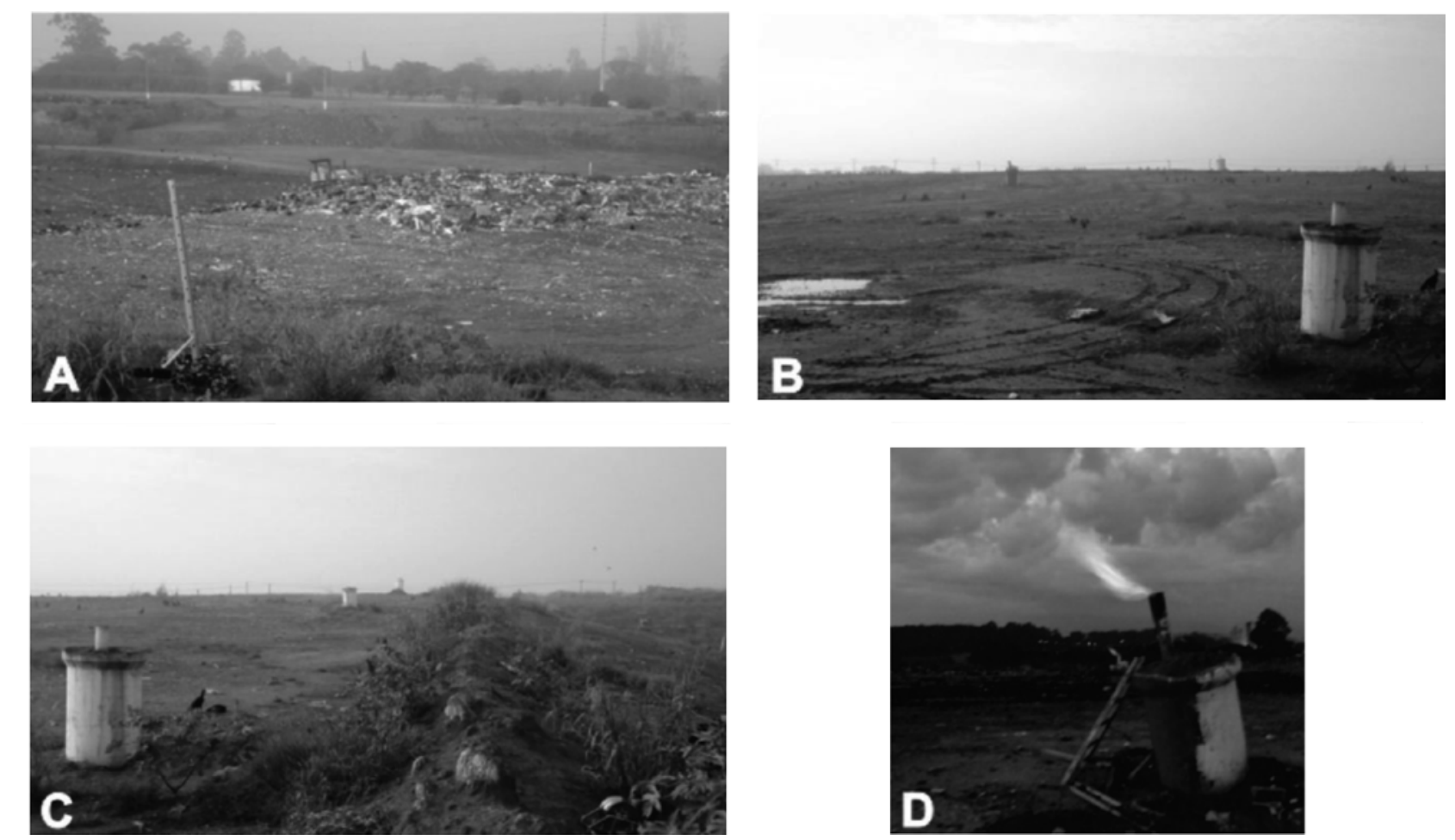

Figure 2 - A) Waste disposal in active cell. B) Partial view of studied cell. C) Guidance of drains crossed by line 2. D) Drain number 28 with burning of biogas.

The geological setting of the area of study is represented by sedimentary rock gathered in Corumbataí and Rio Claro formations. The Corumbataí Formation consist in mudstones, siltstones and purplish and reddish-brown shale, sometimes greenish, with interbedded sandstones, carbonate beds and coquina. The Rio Claro Formation consist in fine and medium sandstones with varied coloration, such as whitish, yellowish, reddish and purplish.

The Self-potential method consist in conducting readings of natural electric field, without any need for circuits of injection of electrical current or generation of electromagnetic field (Keller \& Frischknecht, 1966; Milson \& Eriksen, 2011).

Its advantage lies in the simplicity of the instrumental involved and in the versatility in data acquisition in small areas, besides the range of variation of the physical parameter when measured in the geological environment. The main disadvantages associated with the method are the need for connecting cables, nonpolarizable electrodes, besides the high susceptibility to noise produced by electrical systems such as transformers and electric motor.

Regarding the phenomena of generation of self-potential are classified as mineral, electrolyte and electrochemical potential (Mussett \& Khan, 2000; Telford et al., 2004).
The mineral potential arises due to geochemical reactions of oxidation/reduction in an ore body, equivalent to the galvanic cell defined by Electrochemistry. The electrolytic potential is assigned to the flow produced by the passage of fluid with dissolved salts, in a porous or fractured medium, which potential difference is measured by geophysical instruments.

The electrochemical potential can be originated from processes such as the attack of microorganisms in organic compounds (biodegradation) in a context of soil or rock with hydrocarbons or organic matter.

Thus, this method allows measures of total natural electric potential, where the measured values can be influenced by more than a phenomenon of potential generation.

The household waste generated in Brazil present in an expressive quantity of the organic matter, composed by food scraps. This waste is often covered with successive layers, subsequently isolated from atmospheric contact by a layer of soil after the complete filling of the deposition cells. This context allows for the installation of reducing physical and chemical conditions in the waste, something that contributes to the proliferation of colonies of anaerobic microorganisms. The action of these microorganisms in organic compounds results 
in the generation of electrical potential, whose contrast with a reference point allows for measurements by means of geophysical instruments.

The procedure for data acquisition was started from the selection of two gas wells that have different characteristics due to the age of deposition of waste, described in detail in Antonio (2012).

The drain 5 crosses oldest waste, whose basal portion goes back to the beginning of the operation of the landfill, exhausted a 5 year, while the drain 28 is located in a region with waste that were released a 3 months and reached maximum capacity. Later, measurements of composition and flow of the gases emanating from these two ducts were made by means of the equipment Lantec GEM-2000, which allows for the measurement of concentrations of $\mathrm{CO}_{2}, \mathrm{CH}_{4}$ and $\mathrm{O}_{2}$, as a percentage, as well as measures of the biogas temperature by Antonio (2012). The flow rate was found from the biogas speed, found from
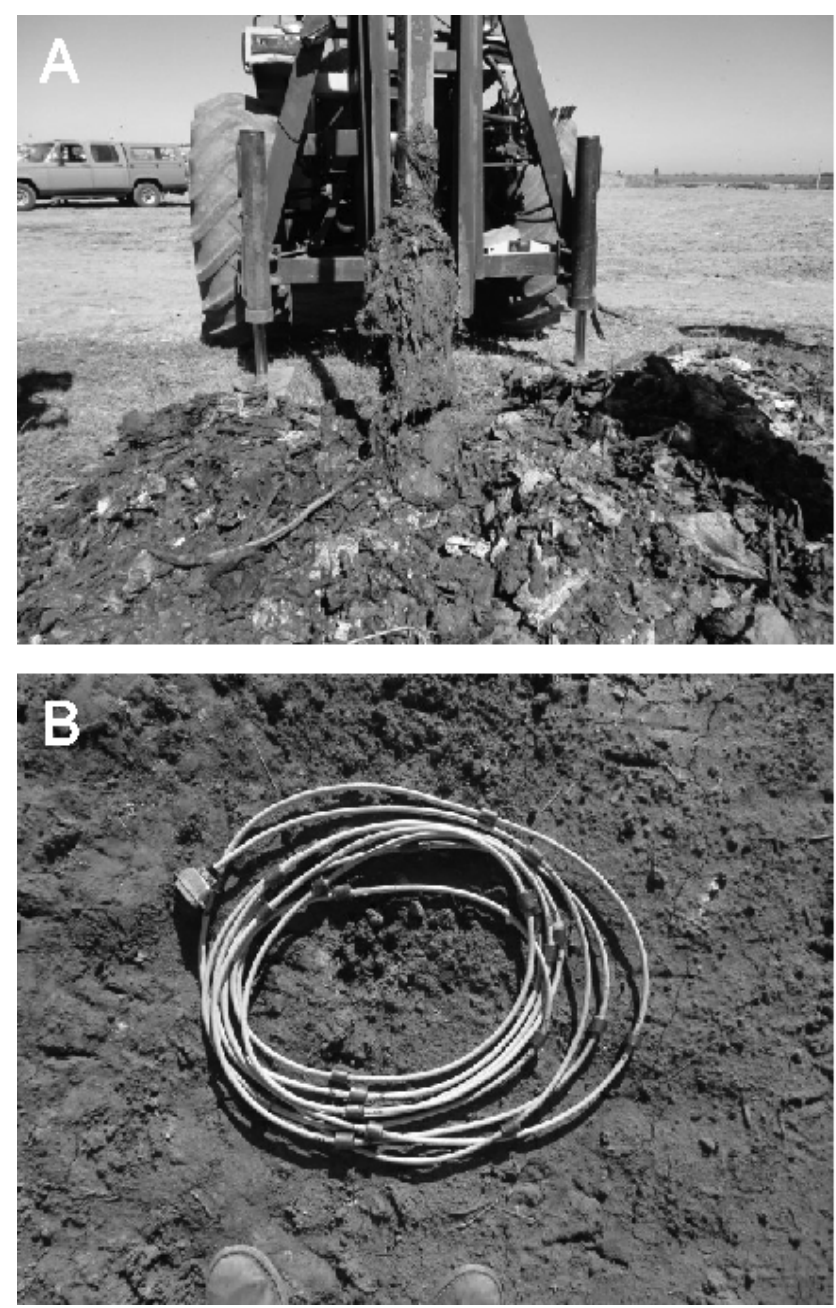

a thermo-anemometer inserted into each drain.

The geophysical logging technique for reading the natural electric potential in fixed base arrangement, with movement of the reading points by depth and reference electrode represented by the nearest sensor to the surface was used, by means of cables made up with sensors based on graphite and spaced every $40 \mathrm{~cm}$, buried in vertical drilling performed alongside 2 drains of biogas (Figure 3 ).

The routine for data acquisition consisted of two weekly readings for one year (May 2011 to May 2012), in an attempt to provide analysis related to climate variability and its influence on geophysical measurements and biogas flow in drains with different productions.

The resistivity meter Terrameter SAS 4000 was used (Figure 3), which enables readings of electrical resistivity, chargeability and natural electric potential, through periodic cycles of reading on programmed time intervals (ABEM, 2006).
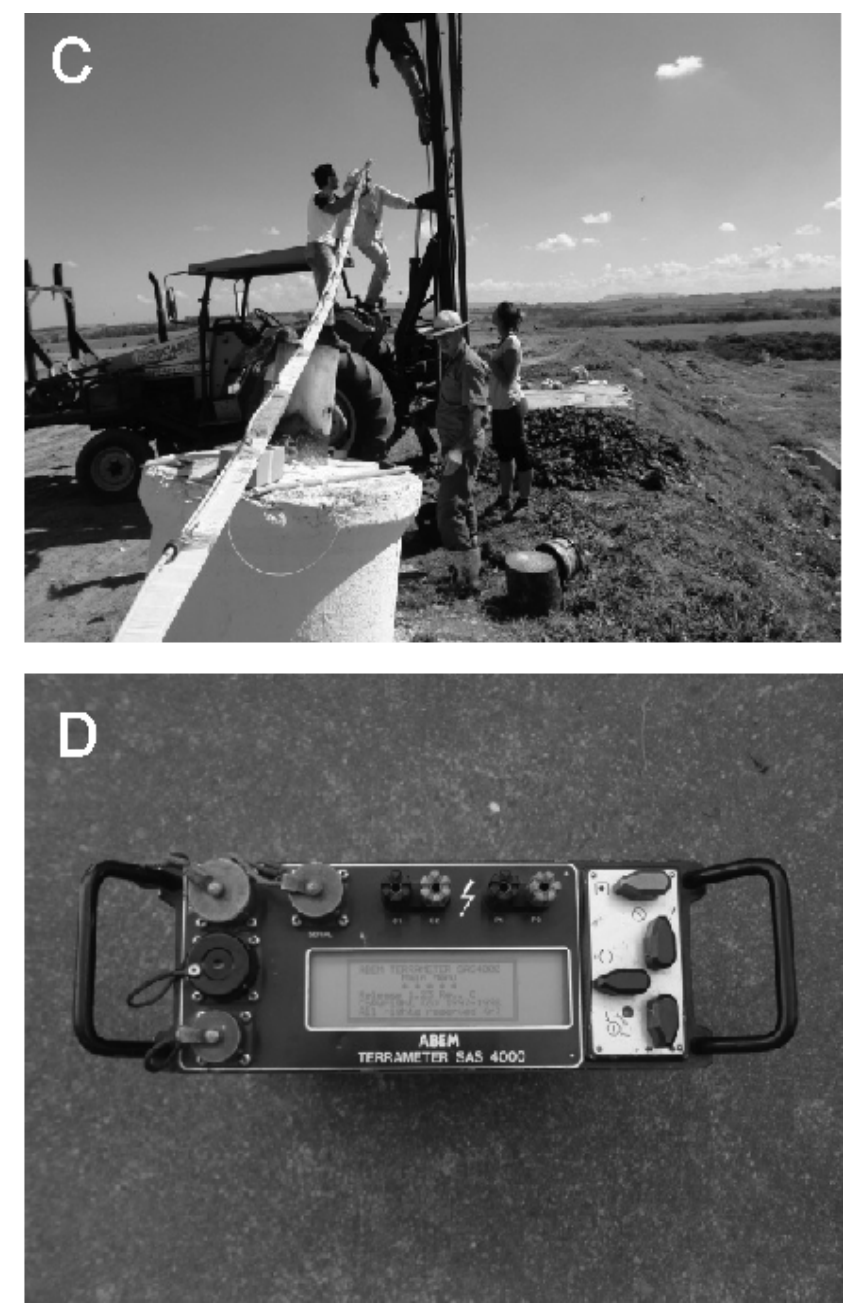

Figure 3 - A) Well perforation. B) Cable for natural electrical potential measures. C) Installation procedure. D) Measuring equipment (resistivity meter). 


\section{DISCUSSION OF RESULTS}

Data were collected fortnightly and tabulated, allowing for the plotting of graphics with the measure of natural electrical potential every $40 \mathrm{~cm}$ from the surface up to a depth of $5 \mathrm{~m}$ (Figure 3).

The data on natural electrical potential indicate values relatively constant with depth up to $4.0 \mathrm{~m}$, where the local water table occurs, represented by the residue completely saturated in leachate, what was proven during the drilling and installation of reading cables. The total thickness of the layer of waste in the regions of drains 5 and 28 range from $17 \mathrm{~m}$ to $20 \mathrm{~m}$, settled on a sheath that water seals the cell from waste.

For May/2011 (dry season), measurement next to drain 5 present an average near $-100 \mathrm{mV}$

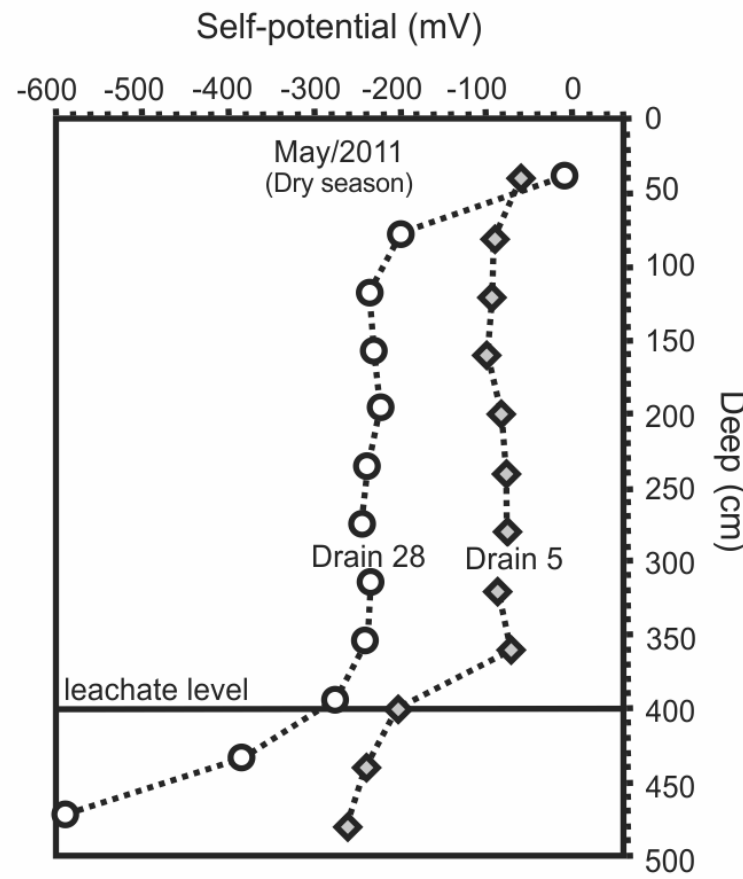

for the interval above the water level, while the measurements for drain 28 present an average around $-250 \mathrm{mV}$. However, for October/2011 (rainy season) as measurement next to drain 5 present an average near $0 \mathrm{mV}$ above the water level, while the drain 28 is variable but present average around $-450 \mathrm{mV}$, also to interval above the water level (Figure 4).

Measurements of biogas flow acquired fortnightly and described in detail in Antonio (2013), are presented graphically in conjunction with rainfall measurements acquired on the same days, both for the 1-year period (May 2011 to May 2012). From the selection of natural electrical potential measurements at $3 \mathrm{~m}$ depth, charts of annual variation, integrated to the rainfall for the period were prepared.

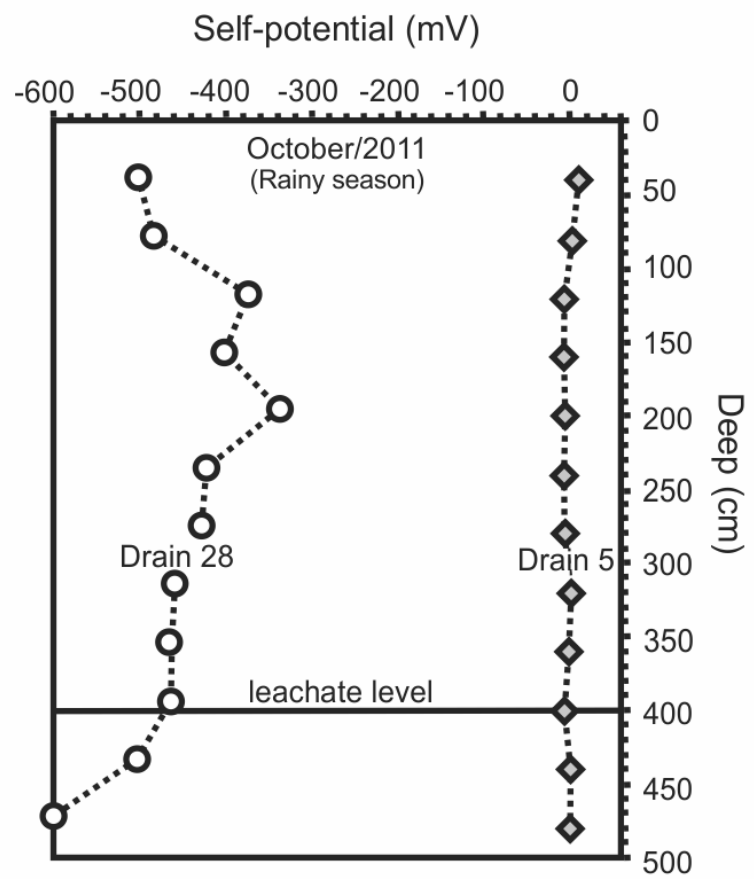

Figure 4 - Measurements of natural electrical potential (in mV) for May/2011 and October/2011 to the drains 5 and 28 , with depth in meters and position of leachate level.

The integrated analysis of the results provides some important considerations on the action of anaerobic degradation processes of organic matter and its effects on change in physical properties in the range unsaturated by leachate.

Among the various factors that affect the generation of gases in solid waste landfills, the most common are related to composition, humidity, temperature and $\mathrm{pH}$ of the waste mass, besides the availability of nutrients and bacteria and presence of inhibitor agents in the cell (El-Fadel et al., 1997; Christensen et al., 2001; Deublein \& Steinhauser, 2010),

Biogeochemical reactions are initiated immediately after coverage of waste in landfills. Organic compounds are oxidized in aerobic processes in shallow locations where aeration occurs by contribution of atmospheric oxygen or infiltration of rainwater, in reactions similar to combustion, generating $\mathrm{CO}_{2}$ and water vapor (Kumar, 2012).

However, the effect of chemical and biological processes is accentuated by 
anaerobic digestion into three main stages (Themelis \& Ulloa, 2007; Deublein \& Steinhauser, 2010).

At first, hydrolysis of complex organic matter occurs by the action of fermentative bacteria in soluble molecules. Then these molecules are converted into simple organic acids such as acetic acid, propionic acid, butyric acid and ethanol, plus $\mathrm{CO}_{2}$ and $\mathrm{H}_{2}$. In the third stage, the generation of $\mathrm{CH}_{4}$ occurs by methanogenic bacteria, by breaking of acids in $\mathrm{CH}_{4}$ and $\mathrm{CO}_{2}$ or by the reduction of $\mathrm{CO}_{2}$ and $\mathrm{H}_{2}$ (Equations 1, 2 and 3).

$$
\begin{aligned}
& \text { (Acetogenesis) } \\
& \mathrm{C}_{6} \mathrm{H}_{12} \mathrm{O}_{6} \mapsto 2 \mathrm{C}_{2} \mathrm{H}_{5} \mathrm{OH}+2 \mathrm{CO}_{2} \\
& \text { equation } 1 \\
& \text { (Methanogenesis) } \\
& \mathrm{CH}_{3} \mathrm{COOH} \mapsto \mathrm{CH}_{4}+\mathrm{CO} \\
& \text { equation } 2 \\
& \mathrm{CO}_{2}+4 \mathrm{H}_{2} \mapsto \mathrm{CH}_{4}+2 \mathrm{H}_{2} \mathrm{O} \\
& \text { equation } 3 \\
& \mathrm{C}_{6} \mathrm{H}_{10} \mathrm{O}_{4}+1,5 \mathrm{H}_{2} \mathrm{O} \mapsto 3,25 \mathrm{CH}_{4}+2,75 \mathrm{CO}_{2} \\
& \text { equation } 4
\end{aligned}
$$

This exothermic reaction releases a small amount of heat and produces a gas with average levels of $54 \% \mathrm{CH}_{4}$ and $46 \% \mathrm{CO}_{2}$. The biogas generated in landfills also contains water vapor near the saturation point, and small amounts of $\mathrm{NH}_{4}, \mathrm{H}_{2}, \mathrm{H}_{2} \mathrm{~S}$ and other minor constituents.

There are many factors to be met in order to exist the continuity of anaerobic process. However, it is essential that there is a constant supply of the main reactant involved in the process, i.e. water (Themelis \& Ulloa, 2007; Deublein \& Steinhauser, 2010).

The mass balance between the organic compound and water in equation 4 indicates that $1 \mathrm{Kg}$ of water enables consumption of 5.4 $\mathrm{Kg}$ of organic matter.

The drains evaluated in the Rio Claro landfill are distant from each other about $200 \mathrm{~m}$ (Figure 2), consisting of waste from the same city, subject to the same processes of release, compaction and covering material, and subjected to the same amount of rainfall.

Therefore, differences in gas flow between the drains are attributable to the amount of organic matter available for anaerobic reactions. The drain region 28 had received the last layer of waste three months from the start of the study, in contrast to the drain region 5, where the last layer of waste dates of 5 years before the studies began. In this sense, the flow of biogas comparatively higher in the drain 28 can be attributed to the age of the waste and the availability of organic matter able to degradation.

The variation in the intensity of the decomposition process of organic waste is reflected in the biogas flow and apparently causes significant changes in physical properties as the natural electrical potential.

Measurements of electrical potential to the drain 5 are relatively constant during the period of 1 year, regardless of the variations of rainfall, characterized by values near $0 \mathrm{mV}$. However, the values for the drain 28 are quite variable, but predominantly negative.

In this case, the two periods where the values are situated close to zero or positive, coincide with periods of drought, which in turn reflect relatively smaller biogas flows in face of the annual average (Figure 5).

The natural electrical potential represents a set of potential prevalent in environments such as landfills. In these sites, rainwater infiltration and lateral migration of leachate occur by gravity action, processes that can result in the generation of streaming potential. Another potential generating factor is the degradation of organic matter contained in the waste, which process involves the flow of electrons, both measured by measures of redox potential.

In face of the high drainage capacity of landfill covering materials and relatively constant flow of leachate towards the lower portions of the landfill, the redox potential must be predominant in the set of generator phenomena of natural electrical potential.

In this sense, the data of natural electric potential to the drain 28 corroborate when compared to the rain in the period. Periods of high rainfall coincide with quite negative values, with contrast to times of drought, where the predominant electrical potential is close to zero or positive. It is likely that the contribution of electrons from the infiltration of rainwater subsequently contributes to reducing 
occurrences, while in periods of drought, filling the pores of the waste layer above the level of leachate is filled with atmospheric oxygen and result in oxidant conditions.

The large peak in the production of biogas for 28 drain occurs about two months after culmination of a period of high rainfall, preceded and succeeded by drought. However, in periods of relatively constant rain, biogas flow in said drain decreases gradually. Apparently, the alternating periods of rain and drought promoted ideal conditions for increasing biogas production in the area of study.
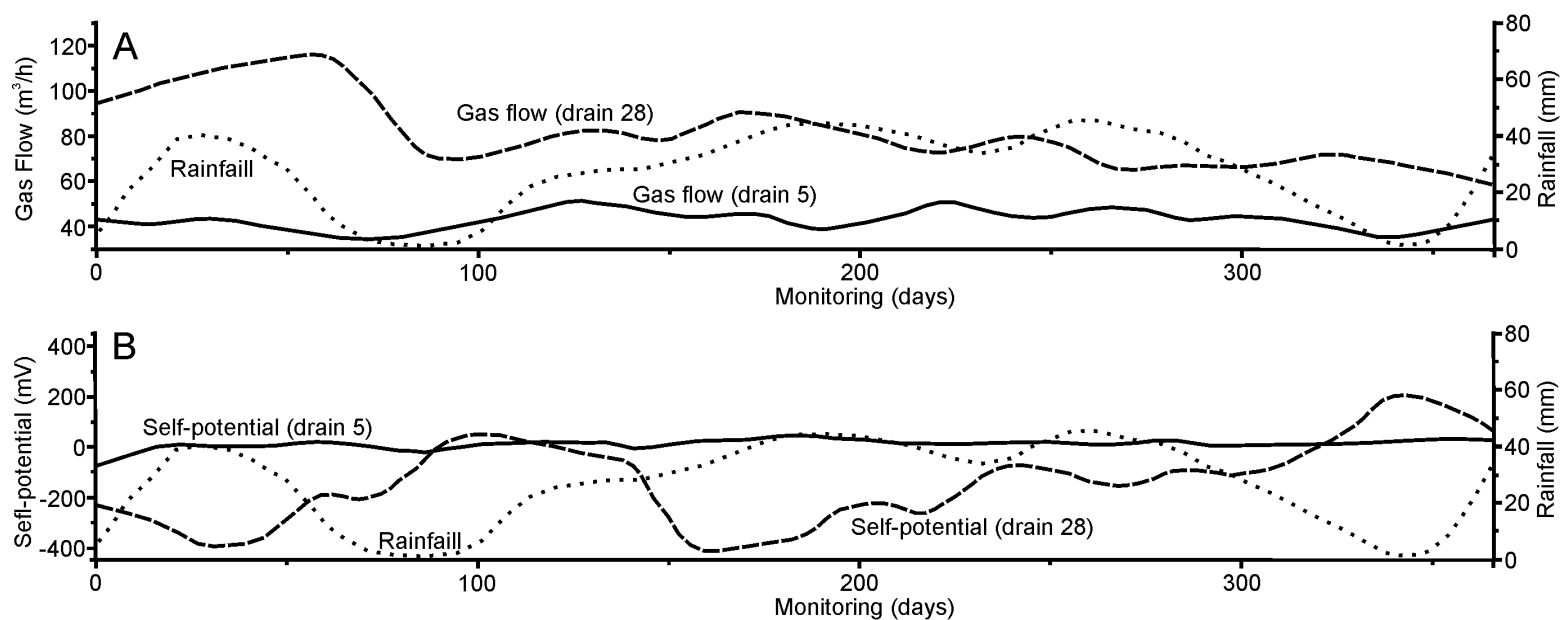

Figure 5 - A) Biogas flow related to rainfall in the period of 1 year. B) Natural electrical potential measured in $3 \mathrm{~m}$ of depth and rainfall for the period of 1 year.

\section{CONCLUSIONS}

Among the variables that control the generation of biogas in landfills, waste age or time of disposition is the main determinant in the area of study.

Age differences of disposition and consequent availability of organic matter likely to degradation, possibly reflect the different biogas production in the points. However, seasonal variations are conditioned by periods of rain and drought.

The natural electrical potential demonstrated proportional variations to biogas flow rates measured in drains with different ages in the landfill studied. For the drain located in recently closed area (3 months) biogas flow was comparatively larger, characterized by very negative electrical potential measurements. In contrast, the drain 5 presented low biogas flow and near-zero measurements, located in an area closed to waste reception for 5 years.

The physical, chemical and biological processes responsible for the consumption of organic matter and biogas generation in landfills are influenced by factors such as rainfall.

The case of higher biogas production occurred about 2 months after a peak of high rainfall, preceded and succeeded by periods of drought.

However, a more frequent and continuous rainfall distribution provided a gradual drop in biogas flow to the drain of higher production.

The intensity of degradation of organic matter and biogas flow is inversely proportional to the natural electric potential, i.e., the largest biogas flow rates are associated to more electronegative or more reducing areas.

Given the relationship between natural electrical potential and biogas production, the adaptation of the technique of geophysical logging for studies in sanitary landfills, demonstrated the potential application of geophysical method of self-potential in studies concerning the generation of biogas in landfills, as well as possibilities for use as diagnostic tool for areas with potential production and collection of biogas for energy purposes.

\section{REFERENCES}

ABEM Terrameter SAS 4000 / SAS 1000 - Instruction Manual, 96 p, 2006.

ANTÔNIO, S.M. Análise da porcentagem de metano presente nos gases gerados no aterro sanitário de Rio Claro e sua relação com o índice pluviométrico. Rio Claro,
2012, 58 p. Trabalho de Conclusão de Curso. Universidade Estadual Paulista.

ASQUITH, G.B. \& GIBSON, C.R. Basic Well Log Analysis for Geologists. Oklahoma: American Association of Petroleum Geologists, 234 p., 1982. 
CETESB/SMA - COMPANHIA AMBIENTAL DO ESTADO DE SÃO PAULO/SECRETARIA DO MEIO AMBIENTE. Biogás: pesquisa e projetos no Brasil. São Paulo: Companhia Ambiental do Estado de São Paulo/Secretaria de Meio Ambiente, 186 p., 2006.

CHRISTENSEN, T.H.; KJELDSEN, P.; BJERG, P. L.; JENSEN, D.L.; CHRISTENSEN, J.B.; BAUN, A.; ALBRECHTSEN, H.; HERON, G. Biogeochemistry of landfill leachate plumes. Applied Geochemistry, v. 16, n. 7, p. 659-718, 2001.

COSTA, A. F.; MALAGUTTI FILHO, W. Caracterização estrutural e geofísica da lixeira de Porto Velho (RO). Geociências (São Paulo), v. 27, n²2, p. 229-236, 2008.

DEUBLEIN, D. \& STEINHAUSER A. Biogas from Waste and Renewable Resources. Heidelberg: Wiley-VCH, 578 p., 2010.

ELLIS, D.V. \& SINGER, J.M. Well logging for Earth Scientists. Netherlands: Springer, 708 p., 2008.

EL-FADEL, M.; FINKAKIS, A.N.; LECKIE, J.O. Environmental Impacts of Solid Waste Landfilling. Journal of Environmental Management, v. 50, n. 1, p. 1-25, 1997.

ENSINAS, V.A. Estudo da Geração de Biogás no Aterro Sanitário Delta de Campinas-SP. Campinas, 2003. 143 p. Dissertação (Mestrado) - Faculdade de Engenharia Mecânica, Universidade Estadual de Campinas.

GEORGAKI, I.; SOUPIOS, P.; SAKKAS, N.; VERVERIDIS, F.; TRANTAS, E.; VALLIANATOS, F.; MANIOS, T. Evaluating the use of electrical resistivity imaging technique for improving $\mathrm{CH}_{4}$ and $\mathrm{CO}_{2}$ emission rate estimations in landfills. Science of the Total Environment, v. 389, p. 522531, 2008.

IPCC - INTERGOVERNMENTAL PANEL ON CLIMATE CHANGE. Guidelines for National Greenhouse Inventories: Reference Manual, 1996.

KELLER, G.V. \& FRISCHKNECHT, F.C. Electrical methods in geophysical prospecting. Oxford: Pergamon Press, 519 p., 1966.

KUMAR, S. Biogas. Rijeka: InTech, 418 p., 2012.

LAQUIDARA, M.J.; LEUSCHNER, A.P.; WISE, D.L. Procedure for determining potential gas quantities in an existing sanitary landfill. Water Science Technology, v. 18, n. 12, p. 151-162, 1986.

MEJU, M.A. Geoelectrical investigation of old/abandoned, covered landfill sites in urban areas: model development with a genetic diagnosis approach. Journal of Applied Geophysics, v. 44, p. 115-150, 2000.

MILSON, J. \& ERIKSEN, A. Field Geophysics. Oxford: John Wiley \& Sons, 232 p., 2011.

MOREIRA, C.A.; BORGES, M.R.; BRAGA, A.C.O.; GODOY, L.H.; SARDINHA, D.S. Relationship between age of waste and natural electric potential generation in Sanitary Landfill. Geofísica Internacional, v. 52, n. 4, p. 375-383, 2013.
MOREIRA, C.A.; BORGES, M.R.; BRAGA, A.C.O.; GODOY, L.H.; SARDINHA, D.S. Electrical resistivity to detect zones of biogas accumulation in a landfill. Geofísica Internacional, v. 54, n. 4, p. 353-362, 2015.

MOREIRA C.A., LAPOLA M.M., CARRARA A. Comparative analyzes among electrical resistivity tomography arrays in the characterization of flow structure in free aquifer. Geofísica Internacional, v. 55, n. 2, p. 119-129, 2016.

MOURA, H. P. ; OLIVEIRA, M. J. ; SACASA, R. J. V. ; ROSARIO, J. M. L. ; MALAGUTTI FILHO, W. ; SOUTO, F. A. F. ; NERY, J. R. C. Emprego da sondagem elétrica vertical com o método da eletrorresistividade no estudo da lixeira pública de Macapá - AP. Geociências (São Paulo) , v. 26, p. 279-286, 2007.

MOURA, H. P. ; MALAGUTTI FILHO, W. . Métodos da eletrorresistividade e da polarização induzida aplicados no estudo do aterro controlado de Piracicaba-SP. Geociências (São Paulo), v. 26, p. 35-43, 2007.

MUSSETT, A.E. \& KHAN, M. A. Looking into the Earth: an introduction to geological geophysics. New York: Cambridge University Press, 492 p., 2000.

NAUDET, V.; REVIL, A.; BOTTERO, J.Y.; BÉGASSAT, P. Relationship between self-potential (SP) signals and redox conditions in contaminated groundwater. Geophysical Research Letters, v. 30, n. 21, p. 1-4, 2003.

OONK, J. \& BOON, A. Landfill gas formation, recovery and emissions. - Institute of environmental and energy technology (TNO). Netherlands: Apeldoorn, 148 p., 1995.

TCHOBANOGLOUS, G. \& THEISEN, H.; VINIL, S Integrated solid waste management. Engineering principles and management issues. New York: Irwin MacGraw-Hill, 978 p., 1993.

TELFORD, W.M. \& GELDART, L.P., SHERIFF, R.E. Applied Geophysics. New York: Cambridge University Press, 792 p., 2004.

THEMELIS, N.J. \& ULLOA, P.A. Methane generation in landfills. Renewable Energy, v. 32, p. 1243-1257, 2007.

USEPA - UNITED STATE ENVIRONMENTAL PROTECTION AGENCY A guide for methane mitigation projects: gas to energy at landfills and open dumps. Washington: United State Environmental Protection Agency, 94 p. 1996 